\title{
Evaluation of the effect of genetically modified Roundup Ready soya bean and MON 810 maize in the diet of Japanese quail on chosen aspects of their productivity and retention of transgenic DNA in tissues
}

Agnieszka Korwin-Kossakowska', Katarzyna Sartowska', Anna Linkiewicz², Grzegorz Tomczyk $^{3}$, Beata Prusak ${ }^{1}$ and Grażyna Sender ${ }^{1}$

'Institute of Genetics and Animal Breeding, Polish Academy of Sciences; Jastrzębiec, Poland, ${ }^{2}$ Reference GMO Laboratory, Plant Breeding and Acclimatization Institute, Radzików, Poland, ${ }^{3}$ National Veterinary Research Institute, Puławy, Poland

\begin{abstract}
The objective of the study was to evaluate the impact of genetically modified (GM) ingredients (soya bean meal and maize grain) used in poultry diets on birds' performance, as well as the accumulation of the transgenic DNA in eggs, breast muscle and internal organs. In the present experiment four generations of Japanese quails, which were subject to three different diets, two containing genetically modified organisms (GMO, soya and maize) and one GMO-free control, were analysed. Birds' performance traits were monitored along the trial. A screening molecular method - polymerase chain reaction amplification (PCR) - was used to detect CaMV 355 promoter and nos terminator in the collected samples. Results showed no presence of modified DNA in the analysed products. According to the obtained results, it was concluded that there was no negative effect of the use of genetically modified soya bean meal or maize grain found with regard to final product safety for consumers or to birds' productivity.
\end{abstract}

Keywords: Japanese quail, Roundup Ready soya bean, MON 810 maize, DNA retention

Abbreviations: EU: European Union, GMO: genetically modified organism, LSM: least square means, PCR: polymerase chain reaction, Bt: Bacillus thuringiensis

Archiv Tierzucht 56 (2013) 60, 597-606

doi: $10.7482 / 0003-9438-56-060$

Corresponding author:

Katarzyna Sartowska; email: k.sartowska@ighz.pl

Department of Animal Immunogenetics, Institute of Genetics and Animal Breeding, Polish Academy of Sciences, Jastrzębiec, Postępu 1, 05-552 Magdalenka, Poland
Received: 6 November 2012 Accepted: 19 March 2013 Online: 26 April 2013

๔ 2013 by the authors; licensee Leibniz Institute for Farm Animal Biology (FBN), Dummerstorf, Germany This is an Open Access article distributed under the terms and conditions of the Creative Commons Attribution 3.0 License

(http://creativecommons.org/licenses/by/3.0/). 


\section{Introduction}

As defined by the European Union (EU), genetically modified organisms (GMOs) are organisms such as plants and animals whose genetic characteristics are being modified artificially in order to give them new properties. Food and feed which contain or consist of such GMOs or are produced from GMOs are called genetically modified food or feed (European Commission 2012).

Farm animals in Europe are fed with GMOs. Their feed usually contains ingredients derived from genetically modified plants, most frequently soya bean meal and maize grain. Soya bean meal is extremely important as a relatively inexpensive source of protein. Most of the soya grown around the world is genetically modified. It is imported to Europe from Brazil, the United States and Argentina, which are the world's leading producers of this plant. The Member States of the EU import approximately 40 million tons of raw soya products annually (European Commission 2010). The situation is completely different when it comes to maize, as Europe is quite self-sufficient. Almost two thirds of the maize production in the EU is used for animal feed. The genetically modified crops currently available at the market are mainly aimed at an increased level of crop protection through the introduction of resistance against plant diseases caused by viruses or insects (referred to as Bt crops, since the gene-conferring resistance comes from the bacterium Bacillus thuringiensis - e.g. MON 810 maize) or through increased tolerance towards herbicides (glyphosate and gluphosinate, e.g. Roundup Ready soya; World Health Organization 2012).

The use of ingredients and products from genetically modified plants in animal nutrition raises many questions and issues such as the role of a nutritional assessment of the modified feed or feed additive as part of safety assessment and the possible influence of genetically modified products on animal health and product quality. Other important issues are the persistence of the recombinant DNA and of the snovek protein in the digestive tract and tissues of food-producing animals (Flachowsky et al. 2005). The European public opinion is clearly concerned about potential risks for human health and the environment. In relation to this discussion, an experiment was conducted based on four generations of Japanese quails which were subjected to three different diets: two containing GMOs and one control group fed without GMOs.

The objective of the study was to perform a comprehensive research excluding or confirming the negative impact of genetically modified plant feed on the birds' performance and as a second step on animal products' safety for consumers. To achieve this goal, the following actions were taken: comparison of the productivity traits of the birds fed with one of three diets and examination of the accumulation of the transgenic DNA in eggs, breast muscle and internal organs in subsequent generations of Japanese quails (treated as model animals).

\section{Material and methods}

\section{Animals, diets and management}

The current trial consisted of four generations of Japanese quails (Coturnix cot. japonica) bred in three parallel feeding groups. In total, 4628 eggs were incubated and 3684 healthy chicks 
entered the trial. At the age of 6 weeks, birds were divided into final flocks of 17 females and 5 males in each cage. Each group consisted of 6 repetitions of such flocks resulting in 102 females and 30 males in each of three groups in four repetitions - generations. In total, 1584 adult birds were used in the trial. During the early laying period (from 7 to 16 weeks of age), eggs were counted daily and the average egg mass was measured once a week in each cage. At the age of 16 weeks, eggs were collected for incubation in order to form the next generation.

Following feeds were used:

A - genetically modified soya bean meal included

$B$ - genetically modified maize grain included,

$\mathrm{C}$ - non- genetically modified materials.

Genetically modified soya bean meal used was produced from Roundup Ready soya beans (Glicyne max. L CV A 5403). Genetically modified maize grain was MON 810 maize with the specific Bt-gene construct. Birds received two types of diet: grower (1-6 weeks) and layer (717 weeks) with the same pattern in all four generations. Experimental feeds were prepared by the feed company Agro-Kocięba (Bogdan Kocięba, Czarnocin, Poland). Details of feed composition are presented in Table 1.

The level of basic nutrients in the above mentioned feeds was analysed in each generation according to methods of AOAC (2005) and it was confirmed to be as planned. Birds in each cage received the same amount of feed and leftovers were monitored weekly.

The content of modified DNA in feeds was examined by a reference GMO laboratory in the Plant Breeding and Acclimatisation Institute (National Research Institute, Radzików, Poland) by a PCR method.

Results confirmed the presence of Roundup Ready soya DNA in group A feed, as well as the presence of MON 810 maize DNA in group B feed but not in other feeds. Group C feed was proven to be free from the above modifications.

\section{Performance traits evaluation}

Basic production performance was recorded in the course of the trial. Weekly body weight was evaluated as average for birds in each cage: weeks 1-4 (brooding period) - all chicks together; weeks 7, 11 and 15 (laying period) - separately for females and males. Weekly laying performance was measured by number of eggs laid divided by number of females in each cage and calculated into laying percentage. Average egg mass was measured on a chosen day in the middle of the week. The remaining part, including incubation, hatching, feed intake, mortality, carcass characteristics, breast muscle composition and egg yolk composition is the subject of earlier work of the current research team (Sartowska et al. 2012). However, the paper covers results of the first two generations.

\section{Sample collection and molecular analysis}

Experimental dissection took place in each generation at the end of the laying period (in week 17). Birds were sacrificed by decapitation. Tissue samples for DNA analysis were collected from a part of the breast muscle, gizzard, liver, spleen, duodenum, kidney and heart from 12 females and 3 males from each feeding group and stored at $-80^{\circ} \mathrm{C}$. Moreover, 
Table 1

Feed composition and nutritional value of feeds used in the experimental diets $A, B$ and $C$

\begin{tabular}{|c|c|c|c|c|c|c|}
\hline \multirow{3}{*}{ Indices } & \multicolumn{3}{|c|}{ Grower feed } & \multicolumn{3}{|c|}{ Layer feed } \\
\hline & \multicolumn{3}{|c|}{ group } & \multicolumn{3}{|c|}{ group } \\
\hline & A & B & C & A & B & C \\
\hline \multicolumn{7}{|l|}{ Ingredients, g/kg } \\
\hline Soya bean meal non-GMO & 0.0 & 390.0 & 390.0 & 0.0 & 295.0 & 295.0 \\
\hline Roundup Ready soya bean meal GMO & 390.0 & 0.0 & 0.0 & 295.0 & 0.0 & 0.0 \\
\hline Maize grain MON 810 GMO & 0.0 & 250.0 & 0.0 & 0.0 & 250.0 & 0.0 \\
\hline Maize grain non-GMO & 250.0 & 0.0 & 250.0 & 250.0 & 0.0 & 250.0 \\
\hline Wheat & 196.7 & 222.0 & 196.7 & 233.3 & 233.8 & 233.8 \\
\hline Triticale & 25.0 & 0.0 & 25.0 & 50.0 & 50.0 & 50.0 \\
\hline Rapeseed meal & 41.7 & 41.7 & 41.7 & 0.0 & 0.0 & 0.0 \\
\hline Rape seed & 0.0 & 0.0 & 0.0 & 55.6 & 55.6 & 55.6 \\
\hline Soya oil & 22.3 & 21.9 & 22.3 & 29.8 & 30.0 & 30.0 \\
\hline Potato protein & 25.3 & 23.1 & 25.3 & 0.0 & 0.0 & 0.0 \\
\hline Maize gluten & 15.5 & 17.8 & 15.5 & 3.1 & 0.0 & 0.0 \\
\hline Limestone & 13.4 & 13.4 & 13.4 & 62.6 & 62.6 & 62.6 \\
\hline Monocalcium phosphate & 9.0 & 9.0 & 9.0 & 9.5 & 9.5 & 9.5 \\
\hline \multicolumn{7}{|l|}{ Additives* } \\
\hline \multicolumn{7}{|l|}{ Nutritional value (calculated) } \\
\hline Energy $\left(\times 10^{3} \mathrm{kcal}\right)^{* *}$ & 2.95 & 2.95 & 2.95 & 2.80 & 2.80 & 2.80 \\
\hline Crude protein, $\%$ & 26.50 & 26.50 & 26.50 & 20.86 & 20.84 & 20.84 \\
\hline Crude fat, $\%$ & 6.10 & 6.04 & 6.10 & 5.54 & 5.56 & 5.56 \\
\hline Crude fibre, $\%$ & 2.79 & 2.80 & 2.79 & 3.01 & 3.01 & 3.01 \\
\hline Ash, \% & 5.85 & 5.85 & 5.85 & 10.39 & 10.39 & 10.39 \\
\hline Ca total, \% & 0.97 & 0.97 & 0.97 & 2.78 & 2.77 & 2.77 \\
\hline$P$ available, $\%$ & 0.45 & 0.45 & 0.45 & 0.45 & 0.45 & 0.45 \\
\hline
\end{tabular}

"The following additives were included in the diets in grower/layer feed $(\mathrm{g} / \mathrm{kg})$ : vitamin-mineral premix 3.2/5, $\mathrm{NaCl} 2.5 / 2.5$, sodium bicarbonate $1.4 / 2.1$, phyzyme $0.1 / 0.1$, ronozyme $0 / 0.2$, methionine $1.8 / 1$, L-lysine $0 / 0.4$ and threonine $0 / 2.3,{ }^{* *} \mathrm{AME}$ : apparent metabolic energy

during week 17 six germinal shields from eggs from each group were collected and stored at $-80^{\circ} \mathrm{C}$. Tissue samples and germinal shields from eggs from each of the feeding groups $(A$, $B$ and $C$ ) were prepared for analyses of specific gene constructs (CaMV 35 S promoter and nos terminator) with the use of PCR analysis. The genomic DNA was extracted from the thawed tissues with the DNeasy Blood and Tissue Kit (Qiagen, Hilden, Germany) according to the manufacturer's protocol. The concentration of DNA was determined by Pico drop Microliter UV/Vis Spectrophotometer (Picodrop Ltd., Hinxton, UK) and the quality of the DNA was checked with an ethidium bromide-stained agarose gel. 
In the first step, the DNA obtained from tissues was tested for integrity by amplification of the species-specific gene. The IGF1 (Insulin growth factor 1) gene fragment specific for avian DNA was amplified using the PCR-RFLP method according to Moody et al. (2003) and Zhou et al. (2005).

The International Standard provides the overall framework of qualitative methods for detection of GMOs in foodstuffs using the PCR method. Qualitative analysis consists of screening and/or specific detection of target nucleic acid sequences in the test samples. The above mentioned method is also used for specific detection and amplification of the sspecific construct of genetically modified plants: CaMV 355 promoter or nos terminator. Due to the presence of these constructs in many genetically modified plants, this method can be used to screen for the presence of genetically modified plant-derived components in animal tissue.

In the second step, the PCR amplification of 1332 examined probes ( 15 animals $\times 3$ feeding groups $\times 7$ tissues $\times 4$ generation and 6 germinal shields $\times 3$ feeding groups $\times 4$ generations) was used for the detection of CaMV 355 promoter and nos terminator.

Specific primers have been used for the detection of CaMV $35 \mathrm{~S}$ promoter ( $p 35 \mathrm{~S}$-cf3, p35S-cr4) and nos terminator (HA-nos188f, HA-nos118r) according to Lipp et al. (2001, Table 2). The protocol of the PCR-based method, allowing the screening of GMOs in analysed material according to Querci et al. (2006), was used. The following reagents were mixed in the preparation of a MasterMix: $0.5 \mu \mathrm{M}$ of each primer, $0.025 \mathrm{U} / \mu \mathrm{l}$ Red Taq polymerase and nuclease-free water aliquots. After amplification of the target sequence, the PCR products were analysed by agarose gel electrophoresis in the presence of ethidium bromide. The gel was photographed to provide a permanent record of the result of the experiment. As positive control, a reference DNA extracted from a certified European Reference Material, Roundup Ready soya (ERM-BF410gk and ERM-BF410dk) and MON810 maize (ERM-BF413f) containing $2 \%$ and $5 \%$ of genetically modified plant ingredients, has been used. The reference material is prepared by JRC-IRMM (Institute for Reference Material and Measurements) which is one of the seven Institutes of the Joint Research Centre (JRC). The DNA from the reference material was extracted using the NucleoSpin Food Kit (Macherey-Nagel, Duren, Germany). The characteristic fragments were amplified by PCR and detected after separation by agarose gel electrophoresis. The positive control is intended to demonstrate what the result of analyses of test samples containing the target sequence will be. As a negative control, IRMM Roundup Ready soya (ERM-BF410a) and IRMM maize (ERM-BF413a) certified reference material containing no genetically modified plant ingredients, have been used. Additionally, a sNo templater sample was created to confirm the purity of the MasterMix, in which water was used instead of DNA.

Table 2

Characteristics of primers for PCR analysis (Lipp et al. 2001, Querci et al. 2006)

\begin{tabular}{llc}
\hline Symbol & Primer sequences & Melting point G/C \\
\hline p35S-cf3 & CCACGTCTTCAAAGCAAGTGG & 57.4 \\
p35S-cr4 & TCCTCTCCAAATGAAATGAACTTCC & 56.3 \\
HA-nos188f & GCATGACGTTATTTATGAGATGGG & 56.2 \\
HA-nos118r & GACACCGCGCGCGATAATTTATCC & 61.2 \\
\hline
\end{tabular}




\section{Statistical analysis}

The analysis of variance (GLM procedure of SAS/STAT 2010, SAS Institute Inc., Cary, NC, USA) was performed to evaluate the differences in the level of the traits between three feeding groups. The analysis was made on data referring to the generations I, II, III and IV. The significance of differences between the values of the traits was estimated by Duncan's test. The models for analysis of variance included fixed effects as follows: for the body weight in the brooding period - the feeding group, subsequent generation, age, feeding groupby-age interaction was used; for the body weight in the laying period - the effects of the feeding group, subsequent generation, sex and age of birds were taken into consideration. Additionally, the interaction of feeding group-by-age-by-sex was used. For the laying rate the effects of the feeding group, subsequent generation, age and feeding group-by-generation, group-by-age and generation-by-age interactions were considered. For the egg weight the effects of the feeding group, subsequent generation, age and feeding group-by-generation, group-by-age interactions were considered.

All procedures were approved by the Local Ethics Commission and performed in accordance with the Guiding Principles for the Care and Use of Research Animals.

\section{Results}

\section{Performance of birds}

Throughout the four generations, the birds' growth was of a similar pattern. The effect of age and generation were significant. The body weight in the brooding period was significantly higher in group $B$ compared to $A$ (Table 3 ), but only in week 4 . At the end of the laying period (week 16), females from group $C$ (non-GMO) were significantly heavier compared to the ones from groups A and B (Table 4). However, these differences were not observed in each of the generations. For the observed time of ten production weeks, the laying rate was at the same level in all three feeding groups, also the average egg weight was the same regardless of the feed used (Table 5).

\section{Molecular analyses}

A fragment of the quail-specific IGF1 gene (813 bp) was amplified to confirm the integrity of the isolated DNA. A $123 \mathrm{bp}$ DNA fragment from the CaMV $35 \mathrm{~S}$ promoter sequence and $118 \mathrm{bp}$ DNA fragment from the nos terminator sequence in reference material were amplified by PCR and detected after separation with agarose gel electrophoresis. In the negative control, no amplification was observed. Typical examples for the amplification results are given in Figures 1 and 2.

Reference material showed the presence of characteristic bands (410gk, 410dk, 413f), whereas the tested samples (1-16 and 1-30, respectively) and reference material with no GMO $(410 \mathrm{a}, 413 \mathrm{a})$ showed no presence of the evaluated gene constructs. There were no CaMV $35 \mathrm{~S}$ promoter sequence or nos terminator sequence amplification in none of the 1332 examined samples derived from examined tissues and germinal shields from each of the feeding groups ( $A, B$ and $C)$. 
Table 3

Quails body weight changes in the brooding period, average of four generations*

\begin{tabular}{lccccc}
\hline Feeding Group & Day 0 & Week 1 & Week 2 & Week 3 & Week 4 \\
\hline A & $7.46 \pm 1.91$ & $26.23 \pm 1.91$ & $41.73 \pm 1.84$ & $82.96 \pm 1.72$ & $116.67 \pm 1.52^{\mathrm{a}}$ \\
B & $7.38 \pm 1.91$ & $27.15 \pm 1.91$ & $43.33 \pm 1.84$ & $86.30 \pm 1.72$ & $121.32 \pm 1.52^{\mathrm{b}}$ \\
C & $7.23 \pm 1.91$ & $26.64 \pm 1.91$ & $43.33 \pm 1.84$ & $84.40 \pm 1.72$ & $119.23 \pm 1.52$ \\
\hline
\end{tabular}

*g; LSM \pm standard error, a,b LSM values in the columns with different letters differ significantly at $P<0.05$

Table 4

Quails body weight changes in the laying period, average of four generations*

\begin{tabular}{lllll}
\hline Feeding group $^{*}$ & & Week 7 & Week 11 & Week 15 \\
\hline \multirow{3}{*}{ Females } & A & 208.243 & 224.409 & $232.806^{\mathrm{a}}$ \\
& $\mathrm{B}$ & 210.159 & 226.063 & $232.212^{\mathrm{A}}$ \\
& $\mathrm{C}$ & 207.442 & 223.084 & $240.673^{\mathrm{B}, \mathrm{b}}$ \\
\hline \multirow{3}{*}{ Males } & $\mathrm{A}$ & 169.216 & 182.626 & 189.134 \\
& $\mathrm{~B}$ & 170.744 & 183.112 & 187.251 \\
& $\mathrm{C}$ & 170.229 & 181.669 & 187.248 \\
\hline
\end{tabular}

${ }^{*} \mathrm{~g}$; LSM \pm standard error (=2.197), ${ }^{\mathrm{a}, \mathrm{b}} \mathrm{LSM}$ values in the columns with different letters differ significantly at $P<0.05$,

$A, B$ LSM values in the columns with different letters differ significantly at $P \leq 0.01$

Table 5

Laying rate and egg mass in three feeding groups, average of four generations*

\begin{tabular}{lccc}
\hline Feeding group & $\mathrm{A}$ & $\mathrm{B}$ & $\mathrm{C}$ \\
& $\mathrm{n}=240^{* *}$ & $\mathrm{n}=240^{* *}$ & $\mathrm{n}=240^{* *}$ \\
\hline Laying rate, \% & $79.11 \pm 0.4473$ & $79.16 \pm 0.4473$ & $78.73 \pm 0.4473$ \\
Egg mass, $\mathrm{g}$ & $11.49 \pm 0.0337$ & $11.53 \pm 0.0334$ & $11.53 \pm 0.0336$ \\
\hline
\end{tabular}

${ }^{*} \mathrm{LSM} \pm$ standard error, ${ }^{* *} \mathrm{n}=6$ cages $\times 10$ weeks of laying period $\times 4$ generations

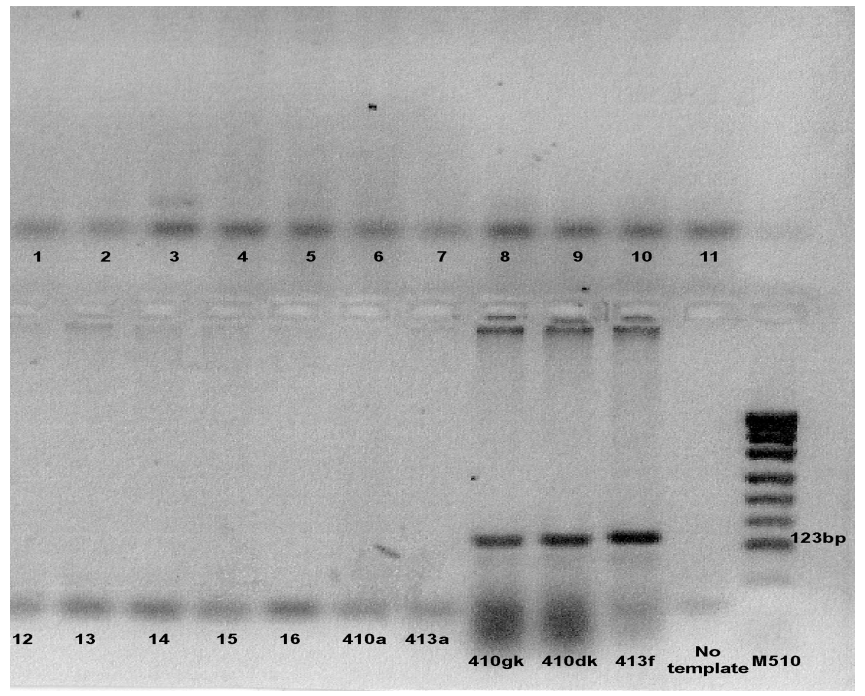

1-16: investigated samples (1-8 breast muscle and 9-16 heart sample, group A, 3rd generation); 410a, 413a: negative control; 410gk, 410dk, 413f: positive control; No template: negative control of the MasterMix, in which water was used instead of DNA; M510: pxUC19 DNA/ Mspl - size marker; 123bp: DNA fragment from the CaMV 35S promoter sequence

Figure 1

Screening of animal tissues for CaMV 35 S component of genetically modified corn (exemplary electrophoretic image) 


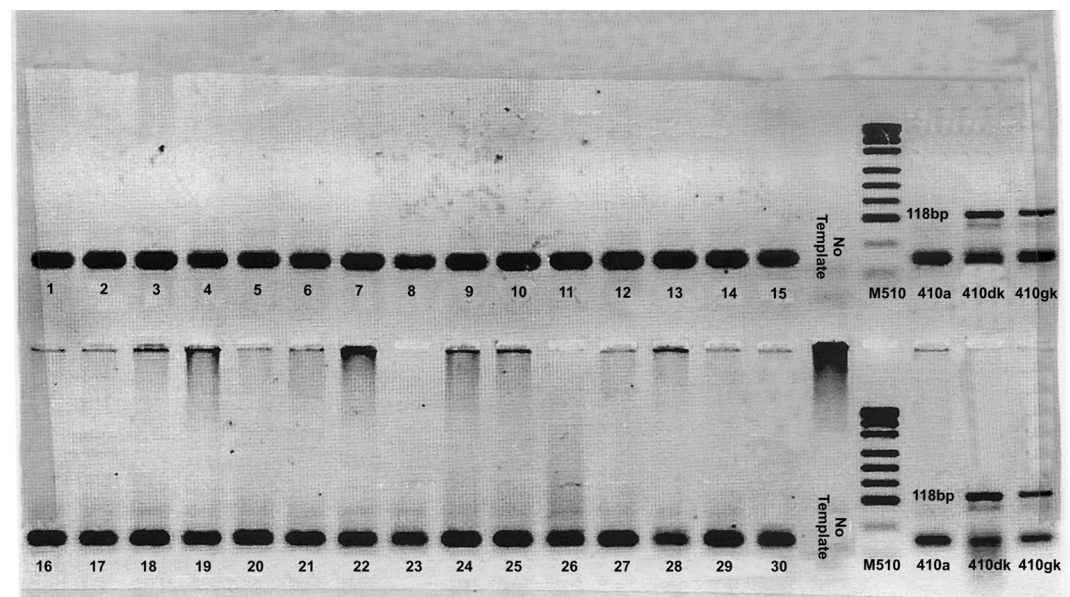

1-30: investigated samples (1-15 breast muscle and 16-30 heart sample, group B, 5th generation); 410a: negative control; 410dk, 410gk: positive controls; No template: negative control of the MasterMix, in which water was used instead of DNA; M510: pUC19 DNA/ $\mathrm{Mspl}$ - size marker; $118 \mathrm{bp}$ : DNA fragment from the nos terminator sequence

\section{Figure 2}

Screening of animal tissues for nos terminator component of genetically modified soya (exemplary electrophoretic image)

\section{Discussion}

So far, there have been performed many studies to demonstrate the effects of genetically modified crops in animal feed on their productivity. The research assessed also whether there is a possibility of retention of the transgenic DNA and the modified protein as the product of its expression in animal tissues (Alexander et al. 2004, Aeschbacher et al. 2005). Poultry such as broiler chicken, laying hen or quail represent a good model species used for this type of research. Generally, these are the animals of low body weight, hence the low cost of living, while having a short reproductive cycle, which allows several generations in a year. Poultry, especially broilers, are particularly sensitive to the quality and nutritive value of feed and the possible content of harmful substances in it. It is also the animal material which is usually available in large quantities. Initial studies around the world indicate a lack of a negative effect of genetically modified feed material on animal organisms (Rossi et al. 2005). Most of these experiments are one-generation research on poultry. Similar results like the absence of modified DNA in poultry products were obtained by other authors (Kan \& Hartnell 2004, McNaughton et al. 2007, Taylor et al. 2007, Świątkiewicz et al. 2010a). The Bacillus thuringiensis-gene specific construct from Bt-corn was not detected in any of the poultry samples, neither in organs, meat nor eggs (Einspanier et al. 2001, Jennings et al. 2003, Aeschbacher et al. 2005, Świątkiewicz et al. 2010b). Also in studies on laying hens, it was found that the modified protein was digested in the gastrointestinal tract of hens and therefore excrement, internal organs (liver) and the eggs were free from transgenic DNA (Ash et al. 2003, Świątkiewicz et al. 2011). Interesting results have also been received by Flachowsky et al. (2005). The diet used in this experiment containing GM maize has been fed 
to quails. Then the birds were observed during the next 10 generations. This is one of a few studies done on many generations of animals. No negative effect was observed in the case of lay, the health of birds, feed efficiency and quality of meat and eggs. On average, male and female quails fed with transgenic maize showed a lower body weight compared to the control receiving genetically modified free feed, but this difference was not significant. There was also no transfer of DNA to the examined tissue samples. The results of our study are in line with results presented in discussed publications. No differences were noted regarding production traits and DNA transfer to tissues. A significant influence of generation number on the evaluated traits was found. However, this could be explained by the different season of the year in different generations. Slight differences between birds' body weight at the end of the brooding period and in the group of females at the end of the laying period, require further analysis in the subsequent generations.

In conlusion, the results of molecular analysis of samples obtained from four generations in this study indicate that the experimental diets containing GMOs (soya bean meal and maize grain) did not affect the results with the presence of modified DNA in examined muscle, internal organs and eggs derived from Japanese quail. No negative effect of the use of genetically modified soya bean or maize was found in the course of the trial with regard to most of the birds' performance traits. These are preliminary results, which do not allow definitive conclusions so far. Further research, evaluating more generations, will be carried out in the future.

\section{Acknowledgements}

Research was realized within the project BIOFOOD - innovative, functional products of animal origin no. POIG.01.01.02-014-090/09 co-financed by the European Union from the European Regional Development Fund within the Innovative Economy Operational Programme 20072013.

The authors gratefully acknowledge Małgorzata Prokopiuk, Agnieszka Roszczyk, Grażyna Faliszewska and Irmina Bieńkowska for technical assistance.

\section{References}

Aeschbacher K, Messikommer R, Meile L, Wenk C (2005) Bt176 corn in poultry nutrition: physiological characteristics and fate of recombinant plant DNA in chickens. Poult Sci 84, 385-394

Alexander TW, Sharma R, Deng MY, Whetsell AJ, Jennings JC, Wang Y, Okine E, Damgaard D, McAllister TA (2004) Use of quantitative real-time and conventional PCR to assess the stability of the cp4 epsps transgene from Roundup Ready (R) canola in the intestinal, ruminal, and fecal contents of sheep. J Biotechnol 112, 255-266

AOAC (2005) Official Methods of Analysis of AOAC International, 18th ed., Gaithersburg, Maryland, USA

Ash J, Novak C, Scheideler SE (2003) The Fate of Genetically Modified Protein from Roundup Ready soybeans in Laying Hens. J Appl Poult Res 12, 242-245

Einspanier R, Klotz A, Krat J, Aulrich K, Poser R, Schwägele F, Jahreis G, Flachowsky G (2001) The fate of forage plant DNA in farm animals: a collaborative case-study investigating cattle and chicken fed recombinant plant material. Eur Food Res Technol 212, 129-134

Flachowsky G, Halle I, Aulrich K (2005) Long term feeding of Bt-corn - a ten-generation study with quails. Arch Anim Nutr 59, 449-451 
European Commission (2012) Health and Consumers http://ec.europa.eu/food/food/biotechnology/index en.htm [last accessed 19.03.2013]

European Commission (2010) Study on the Implications of Asynchronous GMO Approvals for EU Imports of Animal Feed Products. Contract N ${ }^{\circ}$ 30-CE-0317175/00-74 http://ec.europa.eu/agriculture/analysis/ external/asynchronous-gmo-approvals/summary_en.pdf [last accessed 19.03.2013]

Jennings JC, Albee LD, Kolwyck DC, Surber JB, Taylor ML, Hartnell GF, Lirette RP, Glenn KC (2003) Attempts to detect transgenic and endogenous plant DNA and transgenic protein in muscle from broilers fed YieldGard Corn Borer Corn. Poult Sci 82, 371-380

Kan CA, Hartnell GF (2004) Evaluation of broiler performance when fed insect-protected, control, or commercial varieties of dehulled soybean meal. Poult Sci 83, 2029-2038

Lipp M, Bluth A, Eyquem F, Kruse L, Schimmel M, Van den Eede G, Anklam E (2001) Validation of a method based on polymerase chain reaction for the detection of genetically modified organisms in various processed foodstuffs. Eur Food Res Technol 212, 497-504

McNaughton J, Roberts M, Smith B, Rice D, Hinds M, Schmidt J, Locke M, Brink K, Bryant A, Rood T, Layton R, Lamb I, Delaney B (2007) Comparison of Broiler Performance When Fed Diets Containing Event DP356Ø43-5 (Optimum GAT) Nontransgenic Near-Isoline Control or Commercial Reference Soybean Meal, Hulls and Oil. Poult Sci 86, 2569-2581

Moody DE, Haynie J, Schreiweis M, Hester PY (2003) Identification of SNP in candidate genes for osteoporosis in chickens. Proc XI Plant Anim Genome Conf, San Diego, USA, p. 223

Querci M, Jermini M, Van den Eede G (Eds.) (2006) Training course on the analysis of food samples for the presence of genetically modified organisms. User Manual. Institute for Health and Consumer Protection. European Communities, Catalogue number: LB-XI-06-051-EN-C, Printed in Italy

Rossi F, Morlacchini M, Fusconi G, Pietri A, Mazza R, Piva G (2005) Effect of Bt corn on broiler growth performance and fate of feed-derived DNA in digestive tract. Poult Sci 84, 1022-1030

SAS/STAT (2010) User's Guide, Version 9.2, SAS Institute Inc., Cary, NC, USA

Sartowska K, Korwin-Kossakowska A, Sender G, Jozwik A, Prokopiuk M (2012) The impact of genetically modified plants in the diet of Japanese quails on performance traits and the nutritional value of meat and eggs - preliminary results. Arch Geflügelk 76, 140-144

Świątkiewicz S, Świątkiewicz M, Koreleski J, Kwiatek K (2010a) Nutritional efficiency of genetically-modified insect resistant corn (MON810) and glyphosate-tolerant soybean meal (Roundup Ready) for broilers. Bull Vet Inst Pulawy 54, 43-48

Świątkiewicz S, Twardowska M, Markowski J, Mazur M, Sieradzki Z, Kwiatek K (2010b) Fate of transgenic DNA from Bt corn and Roundup Ready soybean meal in broilers fed GMO feed. Bull Vet Inst Pulawy 54, 237-242

Świątkiewicz S, Koreleski J, Arczewska-Włosek A, Świątkiewicz M, Twardowska M, Markowski J, Mazur M, Sieradzki Z, Kwiatek K (2011) Detection of transgenic DNA from Bt maize and herbicide tolerant soybean meal in tissues, eggs and digestive tract content of laying hens fed diets containing genetically modified plants. Ann Anim Sci 11, 413-424

Taylor M, Hartnell G, Lucas D, Davis S, Nemeth M (2007) Comparison of Broiler Performance and Carcass Parameters When Fed Diets Containing Soybean Meal Produced from Glyphosate-Tolerant (MON 89788), Control, or Conventional Reference Soybeans. Poult Sci 86, 2608-2614

World Health Organization (2012) 20 questions on genetically modified foods: http://www.who.int/entity/ foodsafety/publications/biotech/en/20questions_en.pdf [last accessed 19.03.2013]

Zhou H, Mitchell AD, McMurtry JP, Ashwell CM, Lamont SJ (2005) Insulin-like growth factor-I gene polymorphism associations with growth, body composition, skeleton integrity, and metabolic traits in chickens. Poult Sci 84, 212-219 